\title{
PENERAPAN METODE KURABA MOLEKUL UNTUK MENINGKATKAN AKTIFITAS DAN HASIL BELAJAR MATERI TATA NAMA SENYAWA KARBON
}

\author{
Sidiq Subagiyo ${ }^{1}$ \\ ${ }^{1}$ SMA Negeri 1 Lasem
}

\begin{abstract}
Abstrak
Penelitian ini bertujuan untuk mengetahui apakah (1) Penerapan metode pembelajaran Kuraba Molekul dapat meningkatkan aktifitas belajar dan (2) Penerapan metode pembelajaran Kuraba Molekul dapat meningkatkan hasil belajar kognitif. Metode penelitian yang digunakan adalah penelitian tindakan kelas yang terdiri dari dua siklus. Subyek penelitian ini adalah siswa kelas XI IPS SMA Negeri 1 Lasem Tahun Pelajaran 2016/ 2017. Pengambilan sampel menggunakan teknik Purposive Sampling. Sampel adalah kelas XI IPS 4. Data penelitian berupa hasil belajar kognitif dan aktivitas belajar. Pengumpulan data dilakukan melalui observasi, tes, angket, dan dokumentasi. Teknik analisis data menggunakan analisis deskriptif kuantitatif. Dari hasil penelitian dan analisis yang telah dilakukan menunjukkan bahwa: (1) Penerapan metode pembelajaran Kuraba Molekul dapat meningkatkan aktifitas belajar siswa. Keaktifan siswa sebelum tindakan sebesar 30,3\%, pada Siklus I meningkat menjadi 57,58\%, dan pada Siklus II meningkat menjadi $84,84 \%$. (2) Penerapan metode pembelajaran Kuraba Molekul dapat meningkatkan hasil belajar kognitif siswa. Ketuntasan klasikal sebelum tindakan sebesar 27,27\%, pada Siklus I meningkat menjadi 66,67\%, dan pada Siklus II meningkat menjadi 78,78\%.
\end{abstract}

Kata kunci: kuraba molekul, aktifitas belajar, hasil belajar.

\begin{abstract}
This study aims to determine whether (1) The application of Kuraba Molecule_learning method is able to increase learning activity and (2) Application of learning method Kuraba Molecule is able to improve cognitive learning result. The research method used is a classroom action research consisting two cycles. The subjects of this study were students of class XI IPS SMA Negeri 1 Lasem Lesson Year 2016 / 2017. In this research the Sample is taken using technique Purposive Sampling. The sample is class XI IPS 4. Research data in the form of cognitive learning outcomes and learning activities. Data collection is done through observation, test, questionnaire, and documentation. Quantitative descriptive analysis is used to analyse the data. The results of research and analysis show that: (1) Application of Kuraba Molecule learning methods is able improve student learning activities. The activeness of students before the action of $30.3 \%$, in the first cycle increased to $57.58 \%$, and in the second cycle increased to $84.84 \%$. (2) Application of Kuraba Molecule learning method is able to improve student cognitive learning outcomes. The classical completeness before the action was $27.27 \%$, in the first cycle increased to $66.67 \%$, and in the second cycle increased to $78.78 \%$.
\end{abstract}

Keywords: kuraba molecule, learning activity, learning result.

SMA Negeri 1 Lasem

Email: sidiqsubagiyo@gmail.com
(C2018 Universitas Islam Negeri Walisongo 46 ISSN: 2088-7868, e-ISSN 2502-5708 


\section{PENDAHULUAN}

Pemilihan dan penggunaan metode yang tepat dalam menyajikan suatu materi dapat membantu siswa dalam mengetahui serta memahami segala sesuatu yang disajikan guru. Melalui pembelajaran yang tepat, siswa diharapkan mampu memahami dan menguasai materi ajar sehingga dapat berguna dalam kehidupan nyata. Salah satu indikator keberhasilan proses belajar mengajar dapat dilihat dari prestasi belajar yang dicapai siswa. Prestasi belajar adalah cermin dari pengetahuan, keterampilan, dan sikap yang sering disebut sebagai kemampuan kognitif, afektif, dan psikomotor (Wiyono, 2000).

Penerapan struktur kurikulum 2013 pada SMA terbagi menjadi 3 kelompok mata pelajaran yaitu kelompok mata pelajaran wajib, kelompok mata pelajaran peminatan dan kelompok mata pelajaran lintas minat/ pendalaman minat. Ketiga kelompok mata pelajaran tersebut, kelompok mata pelajaran lintas minat banyak menimbulkan kesulitan. Tujuan dari kelompok mata pelajaran lintas minat adalah untuk mengakomodasi perluasan pilihan minat, bakat dan/ atau kemampuan akademik siswa dengan orientasi penguasaan kelompok mata pelajaran keilmuan di luar pilihan minat. Artinya siswa yang mengambil peminatan ilmu matematika dan ilmu pengetahuan alam dapat mengambil mata pelajaran di luar mata pelajaran peminatannya yaitu mata pelajaran peminatan di bidang ilmu-ilmu sosial dan ilmu bahasa dan sastra. Hal ini dapat berpengaruh terhadap minat dan hasil belajar siswa, situasi yang demikian ini juga terjadi di SMA Negeri 1 Lasem khususnya siswa ilmu-ilmu sosial yang mengambil mata pelajaran ilmu matematika dan ilmu pengetahuan alam terutama mata pelajaran kimia. Sehingga siswa mendapatkan hasil yang kurang memuaskan.

Berdasarkan pengamatan proses belajar dan hasil ulangan kelas XI IPS 4 SMA Negeri 1 Lasem diperoleh data kurangnya motivasi atau ketertarikan siswa pada mata pelajaran lintas minat kimia materi tata nama senyawa karbon, hanya 10 siswa yang antusias mengikuti pelajaran dari 33 siswa atau hanya 30,30\%. Sedangkan rata-rata hasil belajar adalah 59,55 dengan ketuntasan klasikal 27,27\% atau 9 anak yang mendapat di atas KKM (75). Data antusiasme dan hasil ulangan tersebut masih sangat jauh dari diharapkan yaitu minimal $80 \%$ siswa antusias dalam mengikuti pelajaran dan rata-rata ulangan sebesar 75 serta ketuntasan klasikalnya $75 \%$.

Proses pembelajaran kimia harus diperhatikan bagaimana siswa mendapatkan pengetahuan (learning to know) melalui pengalaman praktis dengan cara melakukan 
observasi atau eksperimen (learning to do) secara langsung sehingga dirinya berperan sebagai ilmuan, mengaplikasikan ilmu kimia untuk menciptakan hal yang benar demi kepentingan global (learning to live together), dan mempunyai kemantapan emosional dan intelektual (learning to be). Pelajaran kimia di tingkat menengah merupakan pelajaran yang dianggap sulit untuk dipahami, kurang menarik, dan tidak relevan bagi siswa (Prodjosantoso, 2008). Rendahnya minat dan motivasi siswa terhadap kimia karena siswa merasa terpaksa atau suatu kewajiban mempelajari kimia.

Selain itu penggunaan metode pembelajaran yang cenderung monoton dan kurangnya keterlibatan siswa dalam menemukan suatu konsep dalam proses pembelajaran juga menjadi penyebab kimia kurang menarik bagi siswa (Suharyadi, et al., 2013). Ketika guru memberikan pembelajaran yang berkenaan dengan konsep, maka terkadang siswa masih terkesan canggung dan kebinggungan dengan konsep materi pada pembelajaran. Pembelajaran lebih terkesan bersifat teacher-centered, guru hanya menyampaikan materi sebagai produk dan siswa menghafal informasi faktual. Hal ini sejalan dengan yang dinyatakan oleh Brist (2012: 1) bahwa siswa yang mempelajari kimia cenderung diberikan dengan fakta terisolasi dan rumus-rumus kimia yang tidak ada hubungan dengan kehidupan mereka, sehingga mereka cenderung untuk menghafal, kemudian siswa dengan mudah membuangnya tanpa bekas. Pada proses pembelajaran seperti ini, kegiatan siswa selama proses pembelajaran menjadi terabaikan.

Kesulitan pembelajaran kimia terletak pada kesenjangan yang terjadi antara pemahaman konsep dan penerapan konsep yang ada sehingga menimbulkan asumsi sulit untuk mempelajari dan mengembangkannya (Sugiyo, et. al., 2009). Pada penyajian materi kimia agar menjadi lebih menarik, guru harus memiliki kemampuan dalam mengembangkan metode mengajarnya sedemikian rupa sehingga tujuan pembelajaran yang diharapkan pada standar kompetensi dapat dicapai dengan baik (Jusniar, 2009).

Berdasarkan permasalahan tersebut, permasalahan utama penyebab rendahnya prestasi belajar kimia siswa XI IPS 4 SMA Negeri 1 Lasem adalah kurangnya inovasi metode pembelajaran dan proses belajar mengajar yang masih berpusat pada guru (Teacher Centered Learning), sehingga siswa tidak terlibat secara aktif dalam proses belajar mengajar. Oleh karena itu, dibutuhkan peran guru untuk memberikan motivasi serta menjadikan kegiatan belajar mengajar berpusat pada siswa (Student Centered 
Learning) dan menjadikan proses belajar mengajar kimia menjadi menyenangkan sehingga siswa menjadi termotivasi untuk mempelajari kimia.

Salah satu upaya yang dapat meningkatkan aktifitas belajar siswa adalah dengan metode permainan. Metode ini diarahkan agar tujuan belajar dapat dicapai secara efisien dan efektif dalam suasana gembira meskipun membahas hal-hal yang sulit atau berat. Sebaiknya permainan digunakan sebagai bagian dari proses. Metode permainan dalam pembelajaran dapat dilakukan untuk mengembangkan konsep atau untuk mengevaluasi. Permainan pada pembelajaran sebaiknya dirancang dahulu baik skenario maupun alatalat permainannya (Devi, 2016). Metode Kuis Rancang Bangun Molekul (Kuraba Molekul) dapat digunakan sebagai alternatif bentuk permainan dalam proses pembelajaran guna meningkatkan aktifitas dan hasil belajar siswa kelas XI IPS 4 SMA Negeri 1 Lasem pada materi tata nama senyawa karbon.

Kuraba Molekul merupaka bentuk modifikasi model pembelajaran Teams Game Turnament (TGT). Metode ini merupakan salah satu tipe pembelajaran kooperatif yang mudah diterapkan, melibatkan aktivitas seluruh siswa tanpa harus ada perbedaan status, melibatkan peran siswa sebagai tutor sebaya dan mengandung unsur permainan dan penguatan (Slavin, 2008). Pada pembelajaran ini, para siswa dibagi menjadi beberapa kelompok yang terdiri atas empat sampai lima orang yang berbeda-beda tingkat kemampuan, jenis kelamin, dan latar belakang etniknya. Guru menyampaikan pelajaran, lalu siswa bekerja dalam kelompok mereka. Untuk memastikan bahwa semua anggota kelompok telah menguasai pelajaran, selanjutnya diadakan turnamen, dimana siswa memainkan permainan akademik dengan anggota kelompok lain untuk menyumbangkan poin bagi skor kelompoknya (Winarto, R.T. \& Sukarmin, 2012).

Melalui penerapan metode ini dapat menciptakan suasana pembelajaran yang menarik bagi siswa serta dapat meningkatkan keaktifan semua siswa di dalam kelas sehingga siswa menjadi termotivasi dan memiliki minat yang baik untuk belajar (Sutardi, 2013). Metode ini dalam pembelajaran lebih baik daripada metode ceramah (Van Wyk, 2007).

Sesuai dengan suasana seperti ini, siswa selain dapat mengasah kemampuan kognitifnya, juga mendapatkan pengalaman aktivitas langsung, sehingga pembelajaran menjadi lebih bermakna bagi siswa (Umami, 2015). Pembelajaran bermakna membuat siswa dapat menemukan sendiri secara mandiri terhadap fakta dan konsep, 
menumbuhkembangkan nilai-nilai yang dituntut serta merangsang aktivitas siswa (Munandar, 2004).

Berdasarkan uraian di atas, peneliti tertarik melaksanakan penelitian tindakan kelas dengan metode Kuraba Molekul pada materi Tata Nama Senyawa Karbon. Kuraba Molekul dikemas dalam bentuk permainan cerdas cermat dimana salah satu bentuk pertanyaannya adalah merancang model/ rumus bangun molekul dengan menggunakan molymod. Permainan ini didesain untuk menguji pengetahuan yang dicapai siswa yang menekankan kerjasama kelompok, keaktifan siswa dalam mencari jawaban dengan cepat sehingga diperlukan pengetahuan yang cukup sebelum bermain.

Penelitian ini bertujuan untuk mengetahui apakah (1) Penerapan metode pembelajaran Kuraba Molekul dapat meningkatkan aktifitas belajar kelas XI IPS 4 SMA Negeri 1 Lasem dan (2) Penerapan metode pembelajaran Kuraba Molekul dapat meningkatkan hasil belajar kognitif kelas XI IPS 4 SMA Negeri 1 Lasem.

Manfaat yang dapat diperoleh dari penelitian ini bagi profesi guru adalah penelitian ini dapat digunakan sebagai acuan kegiatan pembelajaran di kelas untuk meningkatkan hasil belajar dan mengurangi kejenuhan siswa dalam pembelajaran konvensional di kelas dan dapat meningkatkan kemampuan guru dalam mengajar dan menjadikan sebagai guru yang professional. Manfaat bagi siswa adalah untuk meningkatkan hasil belajar siswa, menambah pengalaman belajar siswa sehingga menciptakan pembelajaran yang berkesan, serta dapat meningkatkan kerja sama antar siswa agar dapat berguna dalam kehidupan sehari-hari. Sedangkan manfaat bagi sekolah, memberikan masukan bagi sekolah dalam upaya meningkatkan kualitas siswa dan hasil belajar siswa.

\section{METODE PENELITIAN}

Penelitian ini merupakan penelitian tindakan kelas. Penelitian ini dilaksanakan dalam 2 siklus yang masing-masing terdiri dari tahap, yaitu: persiapan, perencanaan, pelaksanaan, observasi, dan refleksi. Penelitian ini dilakukan pada semester gasal di SMA Negeri 1 Lasem dengan subyek penelitian adalah siswa kelas XI IPS 4.

Data yang diperlukan pada penelitian ini berupa data aktivitas dan hasil belajar kognitif siswa dengan menggunakan instrumen lembar observasi, angket, dan soal. Teknik analisis data dilakukan untuk mengetahui hasil penelitian berdasarkan tes dan non tes. Data yang diperoleh dari tes dianalisis dengan merekapitulasi hasil belajar nilai 
sebelum penelitian sampai siklus II dan menghitung rata-rata hasil belajar dan ketuntasan belajar klasikal. Untuk menghitung rata-rata hasil belajar tiap tahap menggunakan rumus:

$$
\mathrm{X}=\frac{\text { Jumlah skor total }}{\text { Jumlah siswa }}
$$

$\mathrm{X}=$ nilai rata-rata

ketuntasan belajar klasikal dihitung berdasarkan perbandingan siswa yang tuntas dari jumlah keseluruhan siswa XI IPS 4 menggunakan rumus:

$$
\mathrm{P}=\frac{\text { Jumlah Siswa Tuntas }}{\text { Jumlah Siswa Keseluruha }} \times 100 \%
$$

data observasi keaktifan yang diperoleh dianalisis untuk menghitung skor tiap-tiap siswa sesuai menggunakan rumus:

$$
\mathrm{Y}=\frac{\text { Jumlah skor total tiap siswa }}{\text { Jumlah skor maksimal }} \times 4
$$

$\mathrm{Y}=$ skor observasi siswa

skor observasi tiap aspek dikategorikan menggunakan skala likert sebagai berikut:

1,00-1,75 : Kurang Aktif (KA)

1,76-2,50 : Cukup Aktif (CA)

$$
\text { 2,51-3,25:Aktif (A) }
$$

3,26-4,00 : Sangat Aktif (SA)

Indikator keberhasilan dari penelitian tindakan kelas ini yaitu meningkatnya hasil belajar baik dalam aspek kognitif, afektif, maupun keterampilan merancang bentuk molekul. Adapun aspek-aspek keberhasilan dari penelitian ini adalah (1) Rata-rata nilai kognitif siswa kelas XI IPS 4 materi tata nama senyawa karbon di atas 75, (2) Sekurangkurangnya 75\% siswa kelas XI IPS 4 dapat mencapai ketuntasan hasil belajar, dan (3) Aktivitas siswa di kelas sekurang-kurangnya pada kategori baik (kategori aktif dan sangat aktif) dapat mencapai $75 \%$.

\section{HASIL DAN PEMBAHASAN}

Penelitian Tindakan Kelas (PTK) atau Classroom Action Research (CAR) yang dimaksudkan untuk meningkatkan mutu pembelajaran di kelas dan upaya perbaikan ini dilakukan dengan melaksanakan tindakan untuk mencari solusi atas permasalahan yang ada pada kegiatan sehari-hari di kelas (Kasbolah, K., 2001). Pada PTK, peneliti/ guru 
dapat melihat sendiri pelaksanaan pembelajaran atau bersama dengan rekan sejawat dan dapat melakukan penelitian terhadap siswa dilihat dari aspek interaksinya dalam proses pembelajaran. Melalui PTK guru secara reflektif dapat menganalisis, mensintesis terhadap apa yang telah dilakukan di kelas. Hal ini berarti dengan melakukan PTK, pendidik dapat memperbaiki praktik-praktik pembelajaran sehingga menjadi lebih efektif (Arikunto, S., 2006)

Dalam penelitian ini data yang diperoleh adalah proses dan hasil belajar, yang dimaksud proses di sini adalah aktivitas siswa sedangkan hasil belajar adalah aspek kognitif pada materi tata nama senyawa karbon. Pada penelitian ini soal tes kognitif dan observasi diberikan pada setiap akhir siklus I dan akhir siklus II. Data penelitian tentang aktivitas dan hasil belajar kognitif siswa secara ringkas disajikan pada Tabel 1 dan Tabel 2.

Tabel 1. Rekapitulasi Hasil Aktivitas Siswa

\begin{tabular}{cll}
\hline Siklus & Kriteria & Presentase \\
\hline \multirow{4}{*}{ Pra Siklus } & Sangat Aktif & $0 \%$ \\
& Aktif & $27,27 \%$ \\
& Cukup Aktif & $39,40 \%$ \\
& Kurang Aktif & $33,33 \%$ \\
\hline \multirow{5}{*}{ Siklus I } & Sangat Aktif & $3,03 \%$ \\
& Aktif & $54,55 \%$ \\
& Cukup Aktif & $42,42 \%$ \\
& Kurang Aktif & $0 \%$ \\
\hline \multirow{5}{*}{ Siklus II } & Sangat Aktif & $18,18 \%$ \\
& Aktif & $69,70 \%$ \\
& Cukup Aktif & $12,12 \%$ \\
& Kurang Aktif & $0 \%$ \\
\hline
\end{tabular}

Tabel 2. Rekapitulasi Hasil Belajar Kognitif Siswa

\begin{tabular}{ccc}
\hline Siklus & $\begin{array}{c}\text { Jumlah Siswa } \\
\text { Tuntas }\end{array}$ & $\begin{array}{c}\text { Presentas } \\
\text { e }\end{array}$ \\
\hline Pra Siklus & 9 & $27,27 \%$ \\
\hline Siklus I & 22 & $66,67 \%$ \\
\hline Siklus II & 26 & $78,79 \%$ \\
\hline
\end{tabular}

Berdasarkan data Tabel 1 di atas, keaktifan sebelum diberikan perlakuan, siswa kurang aktif pada pembelajaran. Hal ini terlihat masih banyak siswa yang tidak memperhatikan guru saat menyampaikan materi dan kurang mampu untuk bekerja sama 
dalam kelompok. Setelah diberikan perlakuan pada Siklus I, siswa yang termasuk kategori baik (aktif dan sangat aktif) meningkat menjadi 57,58\%. Sedangkan pada hasil belajar kognitif, juga mengalami peningkatan ketuntasan klasikal menjadi 66,67\% . Namun pada Siklus I belum memenuhi indikator keberhasilan, sehingga harus dilanjutkan ke Siklus II. Pada Siklus I terlihat siswa masih kurang pada aspek memperhatikan jawaban dan memberi penghargaan terhadap hasil kerja kelompok lain. Setelah dilakukan Siklus II, keaktifan dan hasil belajar kognitif siswa juga meningkat. Keaktifan siswa pada Siklus II menjadi 84,84 \% dan ketuntasan klasikal menjadi 78,78 \%.

Peningkatan ini dikarenakan dengan penerapan metode Kuraba Molekul siswa merasa senang dan tertantang untuk mengikuti pembelajaran yang kompetitif. Semua aspek pada keaktifan siswa mengalami peningkatan karena guru lebih mengintensifkan pada pendampingan bagi siswa yang belum aktif agar terdorong untuk lebih berani menyampaikan pendapat atau menanggapi jawaban dalam kegiatan pembelajaran. Guru memberikan kesempatan kepada kelompok yang tidak bermain untuk memberikan tanggapan terhadap jawaban dari siswa yang sedang bermain. Pemberian reward pada akhir siklus juga mampu meningkatkan motivasi siswa untuk mendapatkan poin tinggi. Pembelajaran dengan menerapkan metode pembelajaran Kuraba Molekul ini mampu mendorong siswa untuk terlibat aktif dalam proses pembelajaran. Siswa aktif bertanya, menjawab, dan berdiskusi dalam kelompok untuk memecahkan masalah. Selain itu, metode pembelajaran yang disajikan dalam bentuk permainan ini membuat siswa tidak merasa bosan.

Peningkatan hasil belajar kognitif ini disebabkan pada siklus II, pembelajaran disajikan untuk membahas materi, khususnya pada materi yang belum tuntas. Selain itu, permainan yang dilakukan pada siklus II dilakukan dengan cara soal yang diperoleh siswa didiskusikan terlebih dahulu dengan kelompoknya. Hal ini membuat siswa menjadi lebih menguasai materi pelajaran. Metode pembelajaran dengan memberikan permainan merupakan metode pembelajaran kooperatif dimana siswa bekerja dalam kelompok dan mengajari satu sama lain (Munandar, 2009). Pengelompokkan siswa ini bertujuan untuk menciptakan pendekatan pembelajaran secara efektif yang mengintegrasikan keterampilan sosial bermuatan akademis.

Metode pembelajaran Kuraba Molekul pembelajaran dilakukan dalam kelompok sehingga membuat pembelajaran lebih efektif karena siswa saling bekerjasama untuk 
memahami materi. Kelompok dalam Kuraba Molekul dibuat untuk mempersiapkan anggota, membahas materi secara bersama-sama untuk persiapan menghadapi permainan dan turnamen. Adanya permainan dan turnamen yang melibatkan unsur kompetisi memotivasi siswa untuk memahami materi agar dapat melaksanakan permainan dan turnamen dengan baik. Kompetisi dapat digunakan sebagai alat untuk menumbuhkan tanggung jawab, kerjasama, persaingan sehat dan keterlibatan belajar (Leonard \& Kusumaningsih, 2009). Adanya tanggung jawab individu dan kelompok memungkinkan terjadinya peningkatan sikap positif siswa dalam pembelajaran (Van Wyk, 2007).

Berdasarkan data penelitian ini target keaktifan dan hasil belajar kognitif siswa pada siklus II sudah memenuhi indikator keberhasilan $75 \%$ pada masing-masing aspek. Karena pada aspek tingkat keaktifan siswa mencapai 84,84\% dan ketuntasan klasikal mencapai $78,78 \%$. Adapun peningkatan aspek keaktifan dan hasil belajar kognitif siswa dapat dilihat pada Gambar 1 dan Gambar 2.

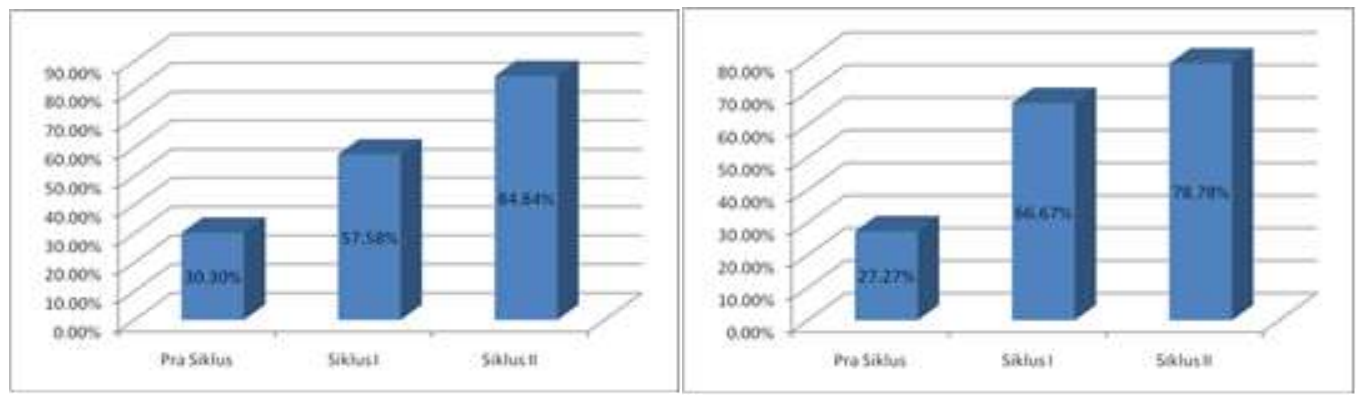

Gambar 1. Peningkatan Keaktifan Siswa Gambar 2. Peningkatan Kognitif Klasikal

\section{SIMPULAN DAN SARAN}

Berdasarkan data hasil penelitian, dapat disimpulkan bahwa (1) Penerapan metode pembelajaran Kuraba Molekul dapat meningkatkan aktifitas belajar kelas XI IPS 4 SMA Negeri 1 Lasem. Hal ini terlihat bahwa keaktifan siswa sebelum tindakan sebesar 30,3\%, pada Siklus I meningkat menjadi 57,58\%, dan pada Siklus II meningkat menjadi $84,84 \%$. (2) Penerapan metode pembelajaran Kuraba Molekul dapat meningkatkan hasil belajar kognitif kelas XI IPS 4 SMA Negeri 1 Lasem. Hal ini terlihat bahwa ketuntasan klasikal sebelum tindakan sebesar 27,27\%, pada Siklus I meningkat menjadi 66,67\%, dan pada Siklus II meningkat menjadi 78,78\%.

Berdasarkan hasil penelitian ini, dapat diberikan saran kepada guru bahwa metode Kuraba Molekul merupakan salah satu metode yang dapat digunakan untuk proses 
pembelajaran yang dapat meningkatkan kualitas pembelajaran, sehingga meningkatkan kualitas pendidikan di Indonesia.

\section{DAFTAR RUJUKAN}

Arikunto, S., Suhardjono \& Supardi. (2006). Penelitian Tindakan Kelas. Jakarta: PT Bumi Aksara.

Brist, A.H. (2012). The Effect Of A Contextual Approach To Chemistry Instruction On Students' Attitudes, Confidence, And Achievement In Science. Proposal for Science Master. Master Programme di Montana University.

Devi, P. K.. (2016). Pengembangan Instrumen Penilaian Pembelajaran. Jakarta: PPPPTK IPA.

Jusniar. (2009). Pengaruh Penggunaan Tutor Sebaya Terhadap Hasil Belajar Kimia Siswa Kelas X SMAN 1 Bajeng (Studi pada Materi Pokok Perhitungan Kimia). Jurnal Chemica, 10(1), 36-43.

Kasbolah, K. (2001). Penelitian Tindakan Kelas. Malang: Universitas Negeri Malang.

Leonard \& Kusumaningsih, K.D. (2009). Pengaruh Model Pembelajaran Kooperatif Tipe Teams Games Tournaments (TGT) terhadap Peningkatan Hasil Belajar Biologi pada Konsep Sistem Pencernaan Manusia. Jurnal Ilmiah Exacta, 2(1), 83-98.

Munandar. (2004). Pengembangan Kreativitas Anak Berbakat. Jakarta: Rineka Cipta. . (2009). Mengembangkan Bakat dan Kreativitas Anak Sekolah. Jakarta: PT. Gramedia.

Prodjosantoso, A.K. (2008). "Pembelajaran Kimia Secara Menarik dan Menyenangkan Pendekatan Relevansi”. Makalah disajikan dalam Seminar Pembekalan Calon Guru Kimia”. 12 Juli 2008. Semarang: Jurusan Kimia FMIPA UNNES Semarang.

Slavin, R.E. (2008). Cooperative Learning: Teori, Riset dan Praktik. Bandung: Nusa Media.

Sugiyo, W., Kusuma, E., \& Wahyuni, P.T. (2009). Efektivitas Metode Student Centered Learning yang Berbasis Fun Chemistry untuk Meningkatkan Hasil Belajar Kimia Siswa. Jurnal Inovasi Pendidikan Kimia, 3(2), 469-475.

Suharyadi, Permanasari, A., dan Hernani. (2013). Pengembangan Buku Ajar Berbasis Kontekstual Pada Pokok Bahasan Asam dan Basa. Jurnal Riset dan Praktik Pendidikan Kimia, 1(1), 60-68.

Sutardi, Rahmi Nuraztia, Sugianto Adi Saputra. (2013). Peningkatan Minat dan Hasil Belajar Siswa Dengan Metode Pembelajaran Quiz Team "Think Fast Do Best" Pada Materi Reaksi Oksidasi-Reduksi di Kelas X MAN Model Singkawang. Jurnal Kaunia, 10 (2).

Umami, Min Z. (2015). Penerapan Cooperative Learning Tipe Teams Games Tournament (TGT) Berbantuan Media Destinasi untuk Meningkatkan Hasil Belajar Stoikiometri Siswa X MIA 3 SMA 1 Bae Kudus. Skripsi tidak dipublikasikan. Semarang: Universitas Negeri Semarang. 
Van Wyk, M.M. (2007). The Effect of Teams-Games-Tournament on Acheivment, Retension, and Attitudes of Economic Education Student. EABR \& ETLC Conference Proceedings. University of the Free State. South Africa. Diakses pada 25 Agustus 2016, dari http:// www.cluteinstitute.com

Winarto, R.T. \& Sukarmin. (2012). Penerapan Zuma Chemistry Game dengan Kooperatif Tipe TGT (Teams Games Tournament) pada Materi Unsur, Senyawa, Campuran di MTsN Surabaya II. Unesa Journal of Chemical Education, 1(1), 180-188.

Wiyono, B.B. (2000). Gaya Kepemimpinan Kepala Sekolah dan Semangat Kerja Guru dalam Melaksanakan Tugas Jabatan Kepala Sekolah Dasar. Jurnal Filsafat, Teori dan Praktik Kependidikan. 